Article

\title{
Benzoic Acid Derivatives of Ifloga spicata (Forssk.) Sch.Bip. as Potential Anti-Leishmanial against Leishmania tropica
}

\author{
Syed Majid Shah ${ }^{1,2}$, Farhat Ullah ${ }^{1, *(\mathbb{D})}$, Muhammad Ayaz ${ }^{1, * \mathbb{D}}$, Abdul Sadiq ${ }^{1}$, Sajid Hussain ${ }^{1,2}$, \\ Azhar-ul-Haq Ali Shah ${ }^{3}$, Syed Adnan Ali Shah ${ }^{4,5}{ }^{\circledR}$, Nazif Ullah ${ }^{6}$, Farman Ullah ${ }^{2}$, Ikram Ullah ${ }^{7}$ \\ and Akhtar Nadhman ${ }^{8}$ \\ 1 Department of Pharmacy, University of Malakand, Chakdara, Khyber Pakhtunkhwa 18800, Pakistan; \\ majidpharma08@yahoo.com (S.M.S.); sadiquom@yahoo.com (A.S.); hussain77pk2003@yahoo.com (S.H.) \\ 2 Department of Pharmacy, Kohat University of Science \& Technology, Kohat 26000, Pakistan; \\ pharmankhan@yahoo.com \\ 3 Department of Chemistry, Kohat University of Science \& Technology, Kohat 26000, Pakistan; \\ izhar_hej@yahoo.com \\ 4 Faculty of Pharmacy, Universiti Teknologi MARA Puncak Alam Campus, Bandar Puncak Alam, \\ Selangor 42300, Malaysia; benzene301@yahoo.com \\ 5 Atta-ur-Rahman Institute for Natural Products Discovery (AuRIns), Universiti Teknologi MARA Puncak \\ Alam Campus, Bandar Puncak Alam, Selangor 42300, Malaysia \\ 6 Department of Biotechnology Abdul Wali Khan University, Mardan 23200, Pakistan; \\ ullahnazif@awkum.edu.pk \\ 7 Suleiman Bin Abdullah Aba-Alkhail center for Interdisciplinary Research in Basic Sciences, \\ International Islamic University, Islamabad 46000, Pakistan; ikram.ullah@iiu.edu.pk \\ 8 Institute of Integrative Biosciences IIB, CECOS University, Peshawar 25000, Pakistan; \\ shamsnazman@gmail.com \\ * Correspondence: farhataziz80@hotmail.com (F.U.); ayazuop@gmail.com (M.A.); \\ Tel.: +92-333-936-1513 (F.U.); +92-346-800-4990 (M.A.)
}

Received: 23 February 2019; Accepted: 4 April 2019; Published: 11 April 2019

\begin{abstract}
This study aimed to appraise the anti-leishmanial potentials of benzoic acid derivatives, including methyl 3,4-dihydroxybenzoate (compound 1) and octadecyl benzoate (compound 2), isolated from the ethnomedicinally important plant Ifloga spicata (I. spicata). Chemical structures were elucidated via FT-IR, mass spectrometry, and multinuclear $\left({ }^{1} \mathrm{H}\right.$ and $\left.{ }^{13} \mathrm{C}\right) \mathrm{NMR}$ spectroscopy. Anti-leishmanial potentials of the compounds were assessed using Leishmania tropica promastigotes. Moreover, acridine orange fluorescent staining was performed to visualize the apoptosis-associated changes in promastigotes under a fluorescent microscope. A SYTOX assay was used to check rupturing of Leishmania promastigote cell membranes using $0.1 \%$ Triton X-100 as positive control. A DNA interaction assay was carried out to assess DNA attachment potential. AutoDock software was used to check the binding affinity of compounds with surface enzyme leishmanolysin gp63 (1LML). Both compounds exhibited considerable anti-leishmanial potential, with $\mathrm{LD}_{50}$ values of $10.40 \pm 0.09$ and $14.11 \pm 0.11 \mu \mathrm{g} / \mathrm{mL}$ for compound 1 and compound 2, respectively. Both compounds showed higher binding affinity with the leishmanolysin (gp63) receptor/protease of Leishmania, as assessed using computational analysis. The binding scores of compounds $\mathbf{1}$ and $\mathbf{2}$ with target gp63 were -5.3 and -5.6 , respectively. The attachment of compounds with this receptor resulted in their entry into the cell where they bound with Leishmania DNA, causing apoptosis. The results confirmed that the investigated compounds have anti-leishmanial potential and are potential substitutes as natural anti-leishmanial agents against L. tropica.
\end{abstract}


Keywords: Ifloga spicata; benzoic acid derivatives; Leishmania tropica; docking; DNA interaction; apoptosis

\section{Introduction}

Leishmaniasis is a major health threat affecting more than 350 million people across the globe and resulting in 70,000 deaths per year [1-4]. It is caused by an intracellular protozoa parasite belonging to the genus Leishmania [5]. Cutaneous leishmaniasis, mainly initiated by Leishmania tropica, is most common in the Northern Areas of Pakistan, and is spreading throughout the country due to the migration of several million refugees [6,7]. This condition is usually self-healing, within 3-18 months, but may sometimes be chronic, and the wounds leave disfiguring spots which lead to public separation and mental pressure. In local communities, herbal therapies are preferred, owing to their safety, efficacy, fewer side effects [8,9], and the unavailability of standard therapies. The rational search for new anti-leishmanial agents can replace the need for current chemotherapies, including those based on antimonial and amphotericin B, which have many undesirable side effects [10-12].

Agathisflavone, camptothecin, quercetin, and sinefungin are phytochemicals which have been isolated from different medicinal plants and have exhibited promising anti-leishmanial potential [13]. Moreover, the investigated compound, methyl 3,4-dihydroxybenzoate, has been isolated from plants Piper glabratum, P. acutifolium, and Asphodelus microcarpus [14-16], and was found to be active against different strains of Leishmania. However, we are reporting, for the first time, the efficacy of methyl 3,4-dihydroxybenzoate and octadecyl benzoate against L. tropica, the most prevalent species of Leishmania in Pakistan. The work is further extended to investigate the preliminary leishmanicidal mechanism of these natural compounds.

Molecular docking studies are an important tool for the discovery of anti-leishmanial compounds [17]. Leishmanolysin (gp63) is a membrane-bound glycoprotein present on the promastigote surface of various species of Leishmania protozoans, and has a key role during Leishmania-induced infection; thus, it can be an attractive target for the discovery of novel anti-leishmanial drugs. [18]. SYTOX assays are used to characterize the membrane distraction potential of substances, as SYTOX dye can pass through the ruptured plasma membrane but cannot cross undamaged membranes, thus distinguishing between dead and living cells [19]. Furthermore, DNA studies are important to check the contact of the agents with Leishmania DNA because damage to DNA halts the replication/transcription process, leading to apoptotic death of Leishmania [20]. Apoptosis is a physiological procedure of cell suicide and in Leishmania species it initiated in response to various anti-leishmanial drugs and nutritional deficiencies [21-24].

Ifloga spicata, which belongs to the family Asteraceae, is an annual herb used as whole plant for the treatment of skin diseases like dermatosis and allergies, and in decoction form for cardiac diseases [25-27]. Approximately 20 different species of the Asteraceae family have been found to possess anti-leishmanial potentialities [28]. The purpose of this study was to isolate and purify the compounds and evaluate their anti-leishmanial potentials against $L$. tropica, along with the possible mechanism.

\section{Materials and Methods}

\subsection{General Experimental}

NMR spectrometer, Bruker AVANCE $500 \mathrm{MHz}$, was used to record the ${ }^{1} \mathrm{H}$ and ${ }^{13} \mathrm{C}$ spectra. IR and, mass (EI and HERI-MS) spectra were recorded on a JASCO A-302 and variant mass spectrometer, respectively. Extraction was carried out with methanol (Daejung CAS No.67-56-1) while chromatographic isolation was performed with the help of organic solvents $n$-hexane (Daejung CAS No.110-54-3), chloroform (Daejung CAS No.67-66-3), and ethyl acetate (Daejung CAS No.141-78-6). Thin-layer chromatography was performed on a silica gel 60 F254 card (Merck, EMD Millipore 
Corporation, Billerica, MA, USA), while for column chromatography, silica gel (230-400 mesh) was used. Compound spots were observed with ultraviolet light and stained by spraying with a solution of ceric sulphate. The L. tropica cultures were maintained in Medium 199 (M199) (Gibco, Invitrogen, Carlsbad, CA, USA) supplemented with 10\% heat-inactivated fetal bovine serum (PAA Laboratories, $\mathrm{GmbH}$, Austria), $100 \mathrm{U} / \mathrm{mL}$ penicillin (Sigma, Milwaukee, WI, USA), and $100 \mathrm{mg} / \mathrm{mL}$ streptomycin (Bio Basic Inc., Markham, ON, Canada). An ELISA reader (ELx800 BioTek) was for used for MTT assays, while a UV-vis spectrophotometer (Shimadzu, Kyoto, Japan, UV-1800) was used for the DNA interaction study. A fluorescent microscope (Leitz Laborlux) was used to observe apoptosis and membrane permeability.

\subsection{Plant Material, Extraction, and Fractionation}

I. spicata mature plant was collected at the flowering stage in the start of April 2016 from Karak District, Khyber Pakhtunkhwa, Pakistan, and its identification was confirmed by taxonomist Dr. Waheed Murad, Department of Plant Sciences, Kohat University of Science and Technology (KUST), Kohat. A voucher specimen was deposited in the department herbarium with a voucher number (KUH 1002). The whole plant (leaves, flowers, stem, roots) was collected, shade-dried for 15 days, and coarsely crushed using a cutter mill. Maceration was carried out for the powdered plant (18 kg) in $80 \%$ methanol followed by filtration. The filtrate was concentrated at $40{ }^{\circ} \mathrm{C}$ using a rotary evaporator to obtain methanolic extract ( $600 \mathrm{~g}$ with yield $3.8 \%)$. The crude extract $(500 \mathrm{~g})$ was dispersed in distilled water $(500 \mathrm{~mL})$ and sequentially extracted with $n$-hexane, chloroform, ethyl acetate to obtain polarity-based fractions [29-32]. All fractions were subjected to preliminary anti-leishmanial screening, and the ethyl acetate fraction was found to be the most effective.

\subsection{Bioguided Isolation and Characterization}

Column chromatography was performed for the most bioactive ethyl acetate-soluble fraction using a mixture of $n$-hexane/ethyl acetate as the mobile phase, and flash silica gel as the stationary phase. The five eluted sub fractions with mobile phase $n$-hexane/ethyl acetate were obtained. The two eluted sub fractions, fraction 1 and fraction 2 , were subject to repeated column chromatography using a pencil column. Compound $\mathbf{1}(15 \mathrm{mg})$ was obtained from fraction 1 using mobile phase $n$-hexane/ethyl acetate in the ratio 90:10, and compound $2(12 \mathrm{mg})$ from fraction 2 using $n$-hexane/ethyl acetate in the ratio 94:6. The structure of the compounds was confirmed through various spectroscopic methods, like ${ }^{1} \mathrm{H}$ and ${ }^{13} \mathrm{C}$ techniques, including mononuclear (COSY) and heteronuclear correlation experiments (HSQC and HMBC), and a literature survey [33-35].

\subsection{Anti-Leishmanial Activity against Leishmania Promastigotes}

Compounds were dissolved in dimethyl sulfoxide (DMSO) using a concentration of $1 \mathrm{mg} / \mathrm{mL}$ to for stock solutions, which were successively further diluted. About $180 \mu \mathrm{L}$ of M199, $100 \mu \mathrm{L}$ of L. tropica log phase culture, and $20 \mu \mathrm{L}$ of each compound were added to the wells of a microtiter plate and incubated at $24{ }^{\circ} \mathrm{C}$ for $72 \mathrm{~h}$. The viability of the L. tropica promastigotes was observed by the formation of purple formazan crystals in the living cells via mitochondrial dehydrogenase enzyme. The percentage of promastigote survival was measured quantitatively at $540 \mathrm{~nm}$ using a microplate ELISA reader, with Glucantime as a positive control [36].

\subsection{Molecular Docking of Leishmanolysin (gp63)}

AutoDock software was used to analyze the binding affinity of test compounds with surface enzyme leishmanolysin gp63 (PDB code: 1LML) in the form of E-values. 2D structures of test compounds were converted into 3D structure format by using Biovia Discovery Studio Visualizer 2016 client. This software was also used for post-docking analysis and schematic representation of the hydrophobic interactions, number of hydrogen bonds, and amino acid residues involved in the best-docked pose of the compound-receptor complex [37]. 


\subsection{Mechanistic Anti-Leishmanial Studies}

\subsubsection{SYTOX Assay}

This assay was used to check Leishmania promastigotes cell membrane rupturing by using $0.1 \%$ Triton X-100 as a standard. Promastigote culture was added to the 96 -well plate, incubated at $24{ }^{\circ} \mathrm{C}$, and centrifuged at 13,000 rpm for $10 \mathrm{~min}$. Cells were suspended, washed with Hank's buffer salt solution (HBSS) three times, and were resuspended in HBSS along with $1 \mathrm{mM} \mathrm{SYTOX} \mathrm{Green} \mathrm{stain.}$ The plate was kept in the dark for 10-15 min, and a fluorescent microscope was used to check the membrane permeability [38].

\subsubsection{DNA Extraction}

DNA was extracted from Leishmania by adding $100 \mu \mathrm{L}$ of lysis buffer and incubating in a water bath at $60^{\circ} \mathrm{C}$ for $2 \mathrm{~h}$. Organic solvents were added to the above solution and centrifuged at 10,000 rpm for $10 \mathrm{~min}$. Precipitation of DNA occurred via addition of $1 \mathrm{~mL}$ of chilled isopropanol to the aqueous layer and, again, centrifuged using the same conditions. DNA was washed with $70 \%$ ethanol and suspended in Tris-EDTA buffer.

\subsubsection{DNA Interaction Assay}

The assay was carried out by dissolving both compounds and DNA in double de-ionized water $(\mathrm{pH}=7.0)$. Leishmania DNA concentration was measured via absorption spectroscopy, using the molar absorption coefficient of $6600 \mathrm{M}^{-1} \mathrm{~cm}^{-1}$. The UV absorption titrations were performed with and without DNA. Compound-DNA solutions were kept for $10 \mathrm{~min}$ at room temperature, and then a reading was taken [20].

\subsubsection{Apoptosis Analysis Studies}

Acridine orange fluorescent staining assay was performed to visualize the apoptosis-associated changes in L. tropica promastigotes under a fluorescent microscope (Leitz Laborlux). Promastigotes maintained and cultured in RPMI-1640 were incubated in 96-well plates $\left(1 \times 10^{4}\right.$ cells/well $)$ at $25^{\circ} \mathrm{C} \pm 1$ in the presence and absence of both compounds. The cells were harvested and checked for apoptosis-associated changes after $48 \mathrm{~h}$. After the respective periods of incubation were completed, a $10 \mu \mathrm{L}$ suspension of the treated leishmanial cells were transferred to glass slides, to which $1 \mu \mathrm{L}$ $(100 \mu \mathrm{g} / \mathrm{mL})$ of acridine orange was added and the entire suspension was covered with a cover slip. The changes in the morphology and nuclear staining of the cells were observed under a fluorescent microscope coupled with a camera [39].

\subsection{Statistical Analysis}

Experimental results were expressed as mean \pm standard deviation and repeated three times. Two-way analysis of variance (ANOVA) and $t$-tests were performed to determine significant means. GraphPad Prism 5 software was used to calculate $\mathrm{LD}_{50}$ values.

\section{Results and Discussion}

Medicinal plants are playing a significant role in drug discovery and development against numerous disorders [40-44]. The main advantage of medicinal plants as a source of new drugs is the molecular diversity of secondary metabolites in these herbs [45,46]. In the current study, compound 1 (Figure 1) was obtained as amorphous powder. The molecular formula was determined to be $\mathrm{C}_{8} \mathrm{H}_{8} \mathrm{O}_{4}$, based on HREIMS and ${ }^{13} \mathrm{C}$ NMR spectra. The ${ }^{1} \mathrm{H}$ NMR spectrum displayed signals for three aromatic protons, suggesting a tri-substituted benzene ring. The three substituents were easily assigned as two hydroxyl groups and a carbonyl group, keeping in view the molecular formula, $\mathrm{C}_{8} \mathrm{H}_{8} \mathrm{O}_{4}$; resonances in the IR spectrum, 3338, 3186, and 1662; and signals in ${ }^{13} \mathrm{C}$ NMR at $\delta 166.9,148.5$, and $143.0 \mathrm{ppm}$. 
The appearance of two aromatic protons at $\delta 7.61,7.57 \mathrm{ppm}$ showed their presence at ortho positions due to the electron deshielding effect of the carbonyl group supported by HMBC. In addition, all the three protons were chemically and magnetically non-equivalent, reflecting the two hydroxyl groups at the 3 and 4 position of the benzene ring. Proton NMR $\left(500 \mathrm{MHz}, \mathrm{CDCl}_{3}\right)$ signals appeared at 7.61 $(1 \mathrm{H}, \mathrm{s}, \mathrm{H}-2), 7.57(1 \mathrm{H}, \mathrm{d}, \mathrm{J}=8 \mathrm{~Hz}, \mathrm{H}-6), 6.90(1 \mathrm{H}, \mathrm{d}, \mathrm{J}=8 \mathrm{~Hz}, \mathrm{H}-5), 3.89\left(3 \mathrm{H}, \mathrm{s}, \mathrm{OCH}_{3}\right)$, while carbon ${ }^{13} \mathrm{NMR}\left(125 \mathrm{MHz}, \mathrm{CDCl}_{3}\right)$ signals appeared at 166.9 (C=O), 148.5 (C-4), 143.0 (C-3), 123.7 (C-6), 122.7 (C-1), 116.6 (C-2), $114.8(\mathrm{C}-5)$, and $51.9\left(\mathrm{OCH}_{3}\right)$ (Figures 1-3). The data were consistent with previously published data [16,47] (Supplementary Materials Figures S1-S3).<smiles>COC(=O)c1ccc(O)c(O)c1</smiles>

\section{3,4-Dihydroxy-benzoic acid methyl ester}

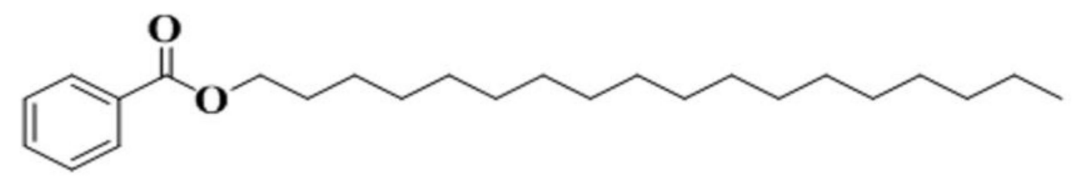

\section{Benzoic acid octadecyl ester}

Figure 1. Chemical structures of the isolated compounds.

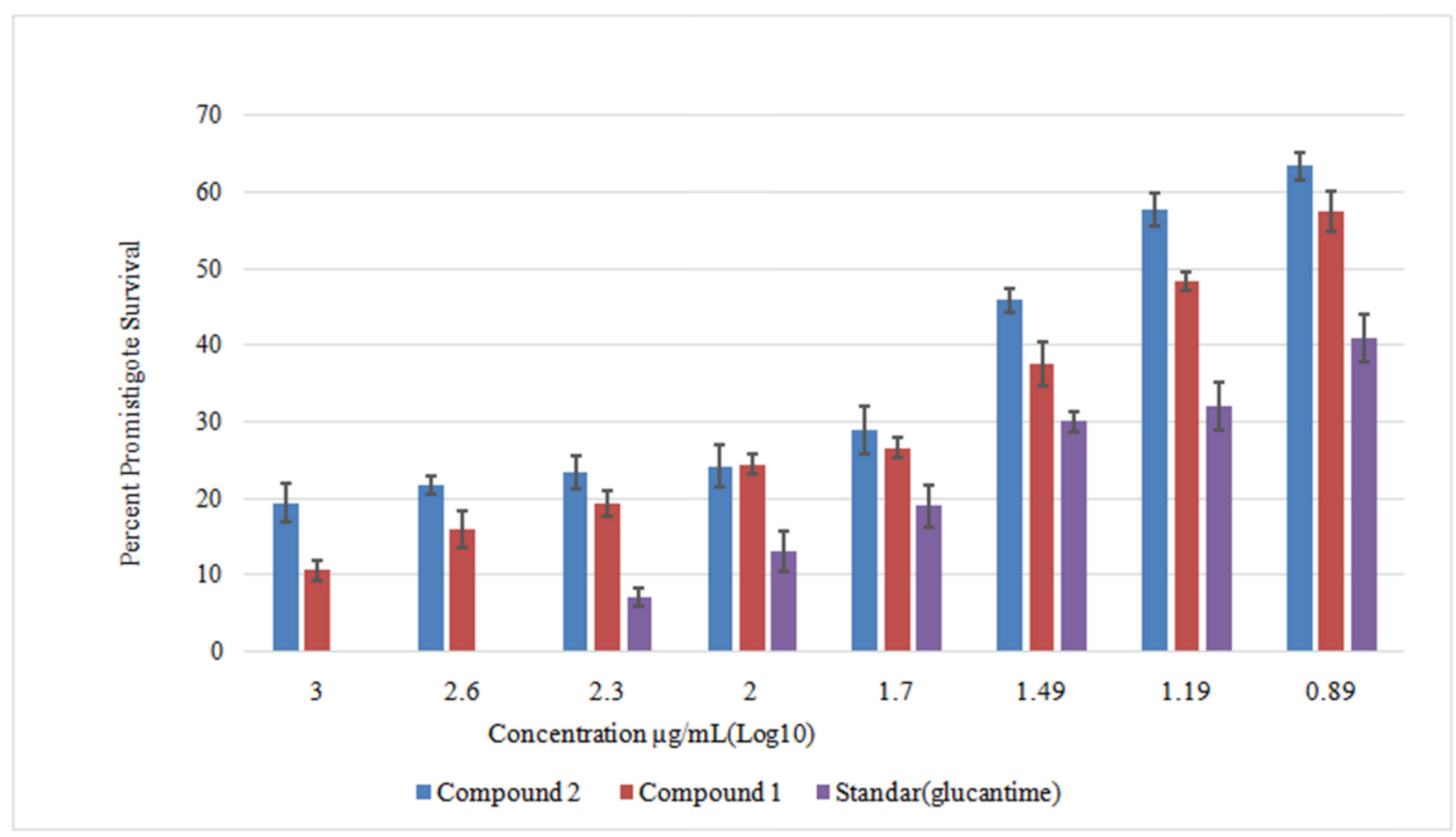

Figure 2. Anti-leishmanial potential of compound $\mathbf{1}$ and compound $\mathbf{2}$ in a dose-dependent assay, depicting promastigote survival after $72 \mathrm{~h}$ of treatment. Bars show significant difference $(p<0.05)$ in survival rates of the parasites of respective groups. Standard drug; Glucantime $\mathrm{LD}_{50}=5.33 \pm 0.07 \mu \mathrm{g} / \mathrm{mL}$.

The structure of compound 2, octadecyl benzoate (Figure 1), was elucidated with the help of IR, EI, NMR spectroscopy (including 2D NMR techniques), and by comparison with the literature [48]. It was obtained as colorless amorphous powder. The molecular formula was determined to be $\mathrm{C}_{25} \mathrm{H}_{42} \mathrm{O}_{2}$, based on HREIMS and ${ }^{13} \mathrm{C}$ NMR spectra. ${ }^{1} \mathrm{H}$ NMR spectrum displayed a triplet at $\delta 0.88$ and a broad 
singlet at $\delta 1.26$, typical of a straight chain hydrocarbon. The ${ }^{13} \mathrm{C}$ NMR spectrum (BB and DEPT) showed 25 signals comprising 1 methyl, 17 methylene, 5 methine, and 2 quaternary carbons. The signal in the downfield region at $\delta 1672$ was assigned to the carbonyl carbons. The oxygenated methylene resonated at $\delta 65.1$. The absence of methine and quaternary carbon in the upfield region suggested that the alkyl chain was linear. This could be further confirmed by the presence of terminal ethyl group (triplet at $\delta 0.88 \mathrm{~J}=7.8 \mathrm{~Hz}$ and multiplet at $\delta 1.26$ ). The benzene ring was found to be monosubstituted due to the presence of three signals each in ${ }^{1} \mathrm{H}$ NMR $\left(8.04\left(\mathrm{~m}, 2 \mathrm{H}, 2^{\prime}, 6^{\prime}\right), 7.4\left(\mathrm{~m}, 1 \mathrm{H}, 4^{\prime}\right), 7.2\left(\mathrm{~m}, 2 \mathrm{H}, 3^{\prime}\right.\right.$, $\left.5^{\prime}\right)$, and ${ }^{13} \mathrm{C}$ NMR $130.6\left(\mathrm{C}-1^{\prime}\right), 129.5\left(\mathrm{C} 2^{\prime}, 6^{\prime}\right), 128.3\left(\mathrm{C}-3^{\prime}, 5^{\prime}\right)$ spectra. Proton NMR (500 MHz, $\mathrm{CDCl}_{3}$ signals appeared at $0.88(3 \mathrm{H}, \mathrm{t}, \mathrm{J}=7.8 \mathrm{~Hz}), 1.26\left(\mathrm{~m},\left(\mathrm{CH}_{2}\right) 9\right), 1.53\left(\mathrm{~m}, \mathrm{CH}_{2}\right), 1.76\left(\mathrm{~m}, \mathrm{CH}_{2}\right)$, and $4.3(\mathrm{~m}$, $\left.\mathrm{CH}_{2}\right)$ while ${ }^{13} \mathrm{C}$ NMR $\left(125 \mathrm{MHz}, \mathrm{CDCl}_{3}\right)$ appeared at $167.0(\mathrm{C}=\mathrm{O}), 132.7\left(\mathrm{C}-4^{\prime}\right), 130.6\left(\mathrm{C}-1^{\prime}\right), 129.5\left(\mathrm{C} 2^{\prime}\right.$, 6'), $128.3\left(\mathrm{C}-3^{\prime}, 5^{\prime}\right), 65.1$ (C-1), 32.0 (C-2), 29.7 (C-3-11), 29.6 (C-16), 29.5 (C-13), 29.3 (C-12), 28.7 (C-14), 26.0 (C-15), $22.7(\mathrm{C}-17)$, and $14.1\left(\mathrm{CH}_{3}\right)$ (Figures 4 and 5 and (Supplementary Materials Figures $\mathrm{S} 4$ and S5)).

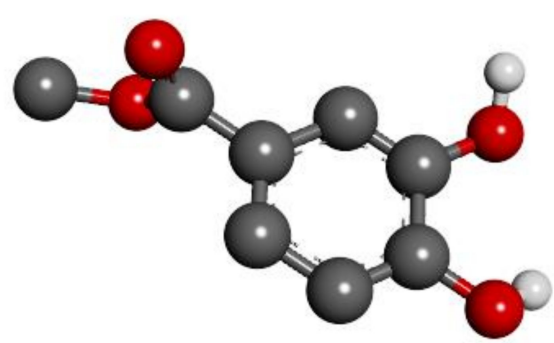

(A)

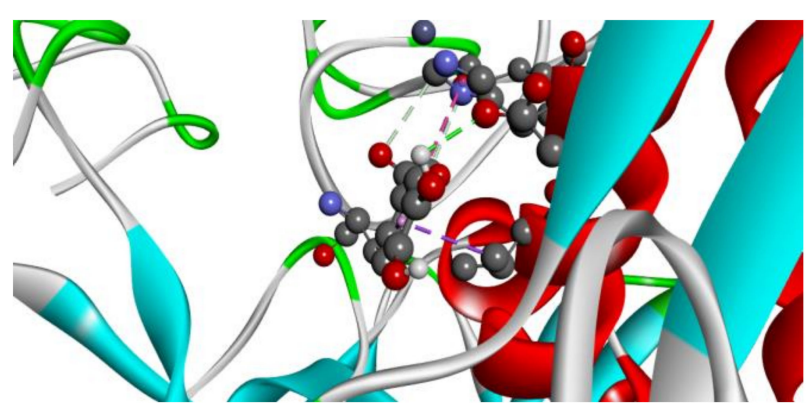

(B)

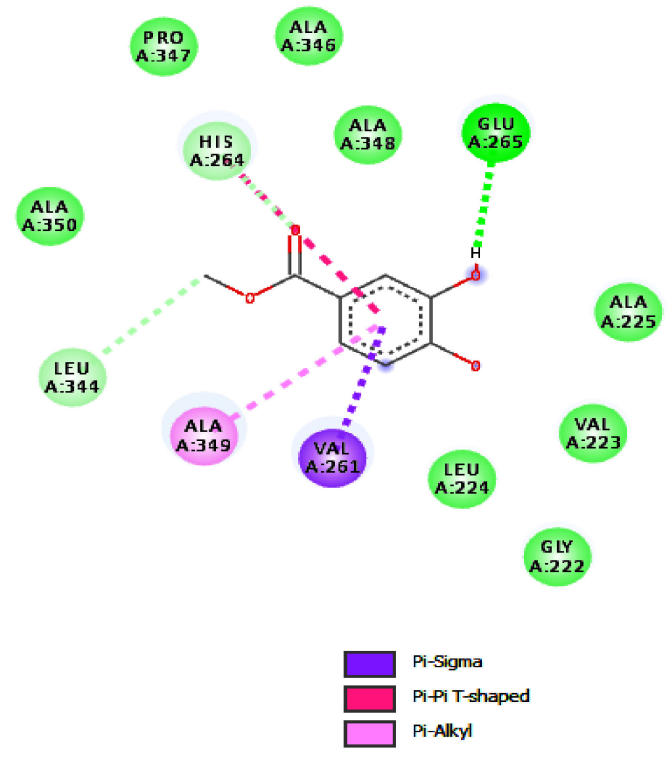

(C)

Figure 3. Interactions of legend (compound 1) with Leishmania tropica promastigote surface gp63 enzyme, drawn through Discovery Studio Visualizer client 2016. (A) PDB structure and best pose of methyl 3,4-dihyroxybenzoate; (B) General interaction of methyl 3,4-dihyroxybenzoate with its targets; (C) Specific interaction of compound $\mathbf{1}$ with its targets. 


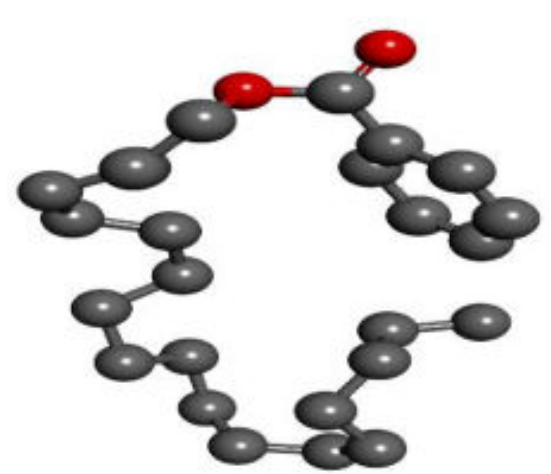

(A)

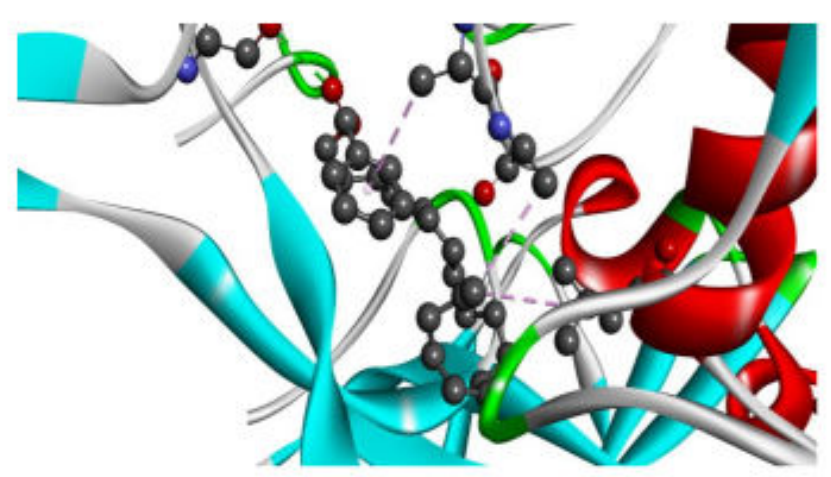

(B)

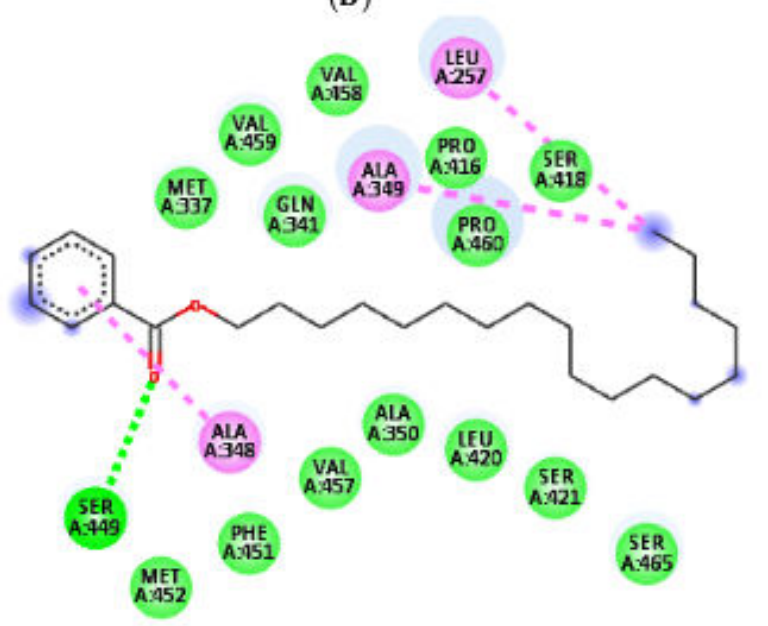

Interactions
$\square$ van der Waals
$\square$ Conventional Hydrogen Bond

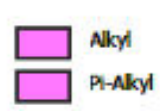

(C)

Figure 4. Interactions of legend (compound 2) with Leishmania tropica promastigote surface gp63 enzyme, drawn through Discovery Studio Visualizer client 2016. (A) PDB structure and best pose of octadecyl benzoate; (B) General interaction of octadecyl benzoate with its targets; (C) Specific interaction of compound 2 with its targets.

Both compounds were evaluated against axenic cultures of $L$. tropica promastigotes. Test compounds exhibited dose-dependent $(7.8-1000 \mu \mathrm{g} / \mathrm{mL})$ anti-promastigote activity with $\mathrm{LD}_{50}$ values of $10.40 \pm 0.09 \mu \mathrm{g} / \mathrm{mL}$ (compound 1 ) and $14.11 \pm 0.11 \mu \mathrm{g} / \mathrm{mL}$ (compound 2) after $72 \mathrm{~h}$ incubation using Glucantime and DMSO as positive and negative controls respectively (Figure 2). The $\mathrm{LD}_{50}$ value of Glucantime was found to be $5.33 \pm 0.07 \mu \mathrm{g} / \mathrm{mL}$. Leishmania exists in two morphological forms, including promastigote and amastigote. Anti-leishmanial studies are usually performed at the promastigote stage because of the short culturing time [49]. The results of this study revealed promising anti-promastigote potentials for both compounds. In previous studies, methyl 3,4-dihydroxybenzoate has been isolated from Asphodelus microcarpus, demonstrating leishmanicidal activity $\left(\mathrm{LD}_{50}=33.2 \mu \mathrm{g} / \mathrm{mL}\right)$ against L. donovani promastigotes [15]. Furthermore, this compound has also been reported from Piper glabratum and P. acutifolium to exhibit strong leishmanicidal activity $\left(\mathrm{LD}_{50} 13.8 \mu \mathrm{g} / \mathrm{mL}\right)$ against L. amazonensis [16]. To the best of our knowledge, this is the first report where both compounds are tested against $L$. tropica, which causes cutaneous leishmaniasis (CL), the prominent clinical form of leishmaniasis that is widespread in Pakistan [50]. Furthermore, we have extended our study in order to 
discover the leishmanicidal preliminary mechanism, which will help in taking the current compounds to the next level of drug discovery.

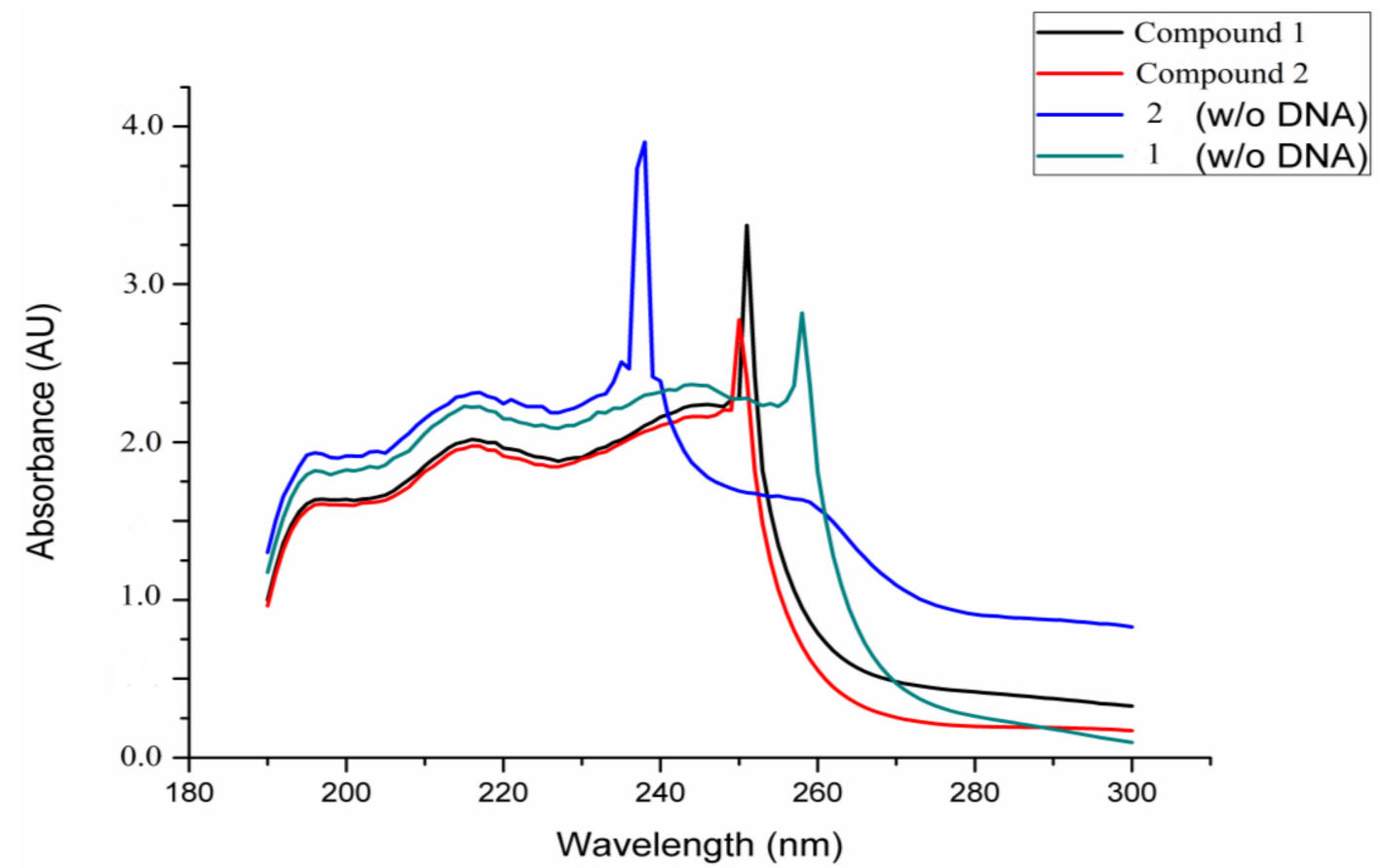

Figure 5. Compound 1 showed hyperchromism (blue shift), while compound 2 presented a hypochromism (red shift) after treatment with Leishmania tropica DNA.

The binding potential of compounds 1 and 2 against gp63 showed significant results. The compounds were assessed on the basis of binding affinity with gp63, in order to rationalize the anti-leishmanial potential in a qualitatively. The E-values for compound 1 and 2 were -5.3 and $-5.6 \mathrm{kcal} / \mathrm{mol}$, respectively. 2D interaction diagrams showing hydrogen bonds of compound 1 and $\mathbf{2}$ with gp63 are presented in Figure 3 and Table 1.

Table 1. E-value $(\mathrm{kcal} / \mathrm{mol})$ and post-docking analysis of best pose of compound $\mathbf{1}$ and $\mathbf{2}$ with GP63 enzyme.

\begin{tabular}{ccccccc}
\hline \multirow{2}{*}{ Targets } & \multicolumn{3}{c}{ Compound 1 } & \multicolumn{2}{c}{ Compound 2 } \\
\hline \multirow{2}{*}{ gp63 } & E-Value & H-Bonds & Bonding Residue & E-Value & H-Bonds & Bonding Residue \\
\cline { 2 - 7 } & -5.3 & 2 & $\begin{array}{l}\text { Glu A:265 } \\
\text { Leu A:344 }\end{array}$ & -5.6 & 1 & Ser A:449 \\
\hline
\end{tabular}

The best-docked pose of ligand-protein complex, determined by minimum binding energy values, number of hydrogen bonds, and residues involved in hydrogen bonding, are summarized in Table 1. gp63 is a membrane-bound glycoprotein which binds to human natural killer cells-which are the first line of defense in numerous infections-and inhibits their proliferation, thus causing leishmaniasis [18]. Compound 1 was docked with the binding pocket of a gp63 receptor, and the results showed that a hydrogen bond was created between -OH of compound 1 with Glu265 residue. Likewise, another hydrogen bond was observed between $-\mathrm{CH}_{2}$ and Leu344. Other multiple interactions were observed: pi-sigma interaction, pi-pi interaction, and pi-alkyl interactions of the benzene ring with Val261, His264, and Ala349, respectively. This showed that compound 1 bounded well to the gp63 receptor.

For compound 2, one hydrogen bond was formed with the benzene ring and Ala348 residue, and pi-alkyl interactions were also observed for the carbonyl oxygen and methyl group $\left(-\mathrm{CH}_{2}\right)$ with Ser449 and Ala349 residues, respectively. The molecular-level interactions that showed binding with the gp63 
involved major hydrophobic protein residues, thus, a drug with more lipophilic groups could more easily bind to gp63 and effectively inhibit its activity [38] (Figure 4). SYTOX green assay was carried out to check membrane damage, and visualization under the fluorescence microscope confirmed that both compounds were responsible for damaging the cell membrane of Leishmania. Full permeability $(100 \%)$ was considered upon treatment with $0.1 \%$ Triton X-100, which was used as positive control. The Leishmania plasma membrane regulates the passage of nutrients, and the homeostasis, to maintain viability. SYTOX dye is a nucleic acid stain which combines with DNA, increasing the fluorescence up to 500-fold, which is observed as a green color [19,39,51].

The DNA interaction study was designed to check the interaction of compounds with Leishmania DNA. The spectrophotometric study showed significant interaction with DNA. Compound 1 showed an interaction with DNA through an increase in the absorption (hyperchromism) and a decrease in absorption wavelength (blue shift), while compound 2 exhibited a decrease in absorption (hypochromism) and an increase in absorption wavelength (red shift), thus confirming the interaction (Figure 5).

Apoptosis is a physiological procedure of cell suicide. It is an integral part of cell biology and occurs in both multicellular and unicellular organisms, including Leishmania promastigotes and amastigotes. Apoptosis greatly affects the survival of a parasite in a vector [21,22]. Acridine orange assays are used to characterize different stages of apoptosis in cells and to check for DNA damage. Acridine orange dye can insert into DNA and emits green fluorescence when bound to normal DNA or dsDNA, and red fluorescence when bound to damaged or ssDNA [38]. For both compounds, early apoptotic (EA) cells started appearing at $12 \mathrm{~h}$ and increased along with the treatment time, whereas late apoptotic (LA) cells were observed after $48 \mathrm{~h}$ of treatment. Compound 2 was not able to induce necrosis like compound $\mathbf{1}$, which made compound $\mathbf{1}$ more effective towards killing L. tropica than compound 2. EA cells had comparatively high motility to that of LA cells, whereas necrotic cells had either completely lost their motility or could only move very slowly. Our results showed that both compounds have apoptotic potential and caused death of L. tropica (Figure 6).

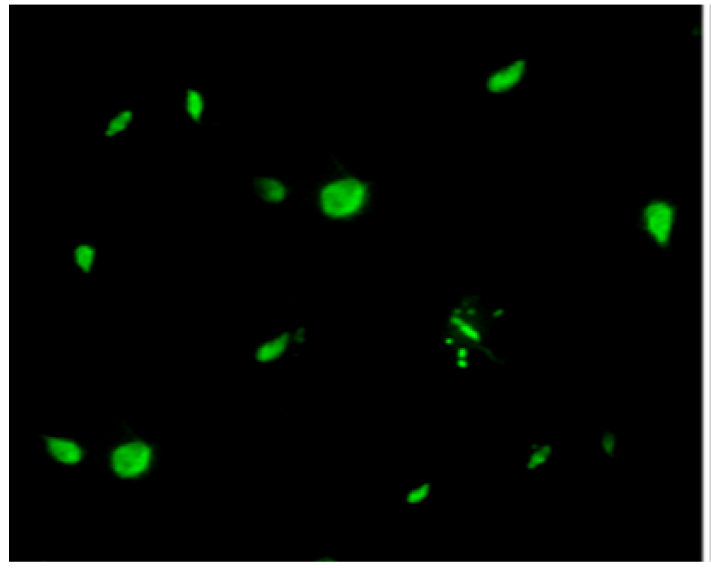

(A)

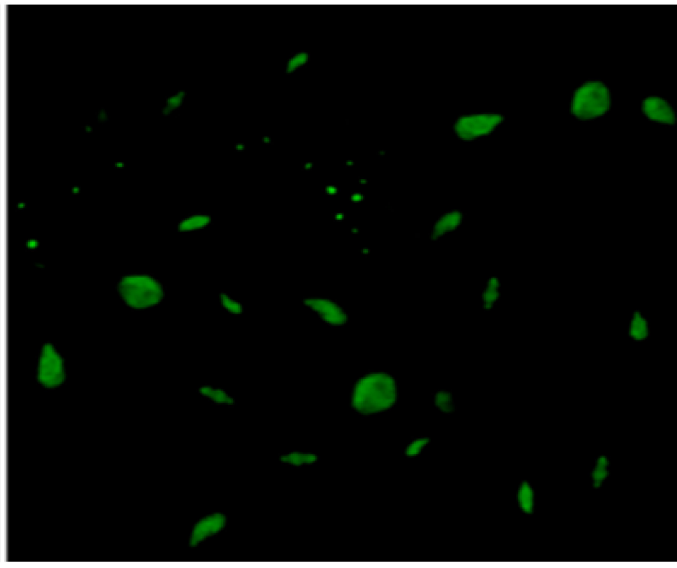

(B)

Figure 6. Apoptosis of Leishmania tropica cells treated with (A) compound $\mathbf{1}$ and (B) compound $\mathbf{2}$ using acridine orange fluorescent staining. Image after $48 \mathrm{~h}$ of treatment; dull green nuclei are indicative of apoptosis.

\section{Conclusions}

A literature survey showed that no plant-derived compound has been approved against leishmaniasis because the rate of isolation of pure compounds from extracts was low, and most of the research was confined to extracts/fractions of plants. Furthermore, some phytochemicals, like methyl curine, chondrocurine, and coumarin, have exhibited significant results against leishmaniasis, but no mechanistic or in vivo studies have been performed to date. This study aimed to isolate pure 
compounds and carry out mechanistic studies to facilitate the development of cost-effective, safe, and efficacious drugs against leishmaniasis. The studied compounds exhibited cell death in L. tropica promastigote through apoptosis, which was further confirmed by DNA interaction and molecular docking studies. In our laboratory, further in vitro studies to evaluate both compounds against the amastigote form of L. tropica are ongoing. Future in vivo trials in rodent models are recommended, followed by determination of therapeutic dose.

Supplementary Materials: The following are available online at http://www.mdpi.com/2227-9717/7/4/208/s1.

Author Contributions: Conceptualization, S.M.S., F.U., A.N., M.A., A.S.; Methodology, S.M.S., A.N., N.U., S.H.; Software, A.-H.A.S., S.A.A.S., A.S.; Validation, F.U., I.U.; Formal Analysis, F.U., M.A.; Writing-Original Draft Preparation, S.M.S., M.A., N.U., I.U., F.U.; Writing-Review \& Editing, M.A., F.U.; Supervision, F.U., A.N. All authors read and approved the final version of the manuscript.

Funding: This research received no external funding.

Acknowledgments: This work was partially funded by Higher Education Commission (HEC) of Pakistan and its support is gratefully acknowledged.

Conflicts of Interest: The authors declare no conflict of interest.

\section{References}

1. Oliveira, F.; Jochim, R.C.; Valenzuela, J.G.; Kamhawi, S. Sand flies, Leishmania, and transcriptome-borne solutions. Parasitol. Int. 2009, 58, 1-5. [CrossRef] [PubMed]

2. Feasey, N.; Wansbrough-Jones, M.; Mabey, D.C.; Solomon, A.W. Neglected tropical diseases. Br. Med. Bull. 2009, 93, 179-200. [CrossRef]

3. Reithinger, R.; Dujardin, J.-C.; Louzir, H.; Pirmez, C.; Alexander, B.; Brooker, S. Cutaneous leishmaniasis. Lancet Infect. Dis. 2007, 7, 581-596. [CrossRef]

4. Santos, D.; Silva, I.B.; Paz, D.; Ribeiro, F.A.C.; Garcia, C.D.M.; Teixeira, A.K.; Maugéri, D.; Katz, L.M.; Barbiéri, S.; Lúcia, C. Leishmanicidal and Immunomodulatory Activities of the Palladacycle Complex DPPE 1.1, a Potential Candidate for Treatment of Cutaneous Leishmaniasis. Front. Microbiol. 2018, 9, 1427. [CrossRef]

5. Sharma, U.; Singh, S. Immunobiology of leishmaniasis. Indian J. Exp. Biol. 2009, 47, 412-423. [PubMed]

6. Shah, N.A.; Khan, M.R.; Nadhman, A. Antileishmanial, toxicity, and phytochemical evaluation of medicinal plants collected from Pakistan. BioMed Res. Int. 2014, 2014, 1-7. [CrossRef]

7. Jamal, Q.; Shah, A.; Ali, N.; Ashraf, M.; Awan, M.M.; Lee, C.M. Prevalence and comparative analysis of cutaneous leishmaniasis in Dargai Region in Pakistan. Pak. J Zool. 2013, 45, 537-541.

8. Ullah, N.; Nadhman, A.; Siddiq, S.; Mehwish, S.; Islam, A.; Jafri, L.; Hamayun, M. Plants as antileishmanial agents: Current scenario. Phytother. Res. 2016, 30, 1905-1925. [CrossRef] [PubMed]

9. De Sarkar, S.; Sarkar, D.; Sarkar, A.; Dighal, A.; Staniek, K.; Gille, L.; Chatterjee, M. Berberine chloride mediates its antileishmanial activity by inhibiting Leishmania mitochondria. Parasitol. Res. 2019, 118, 335-345. [CrossRef]

10. Ahmad, S.; Ullah, F.; Sadiq, A.; Ayaz, M.; Imran, M.; Ali, I.; Zeb, A.; Ullah, F.; Shah, M.R. Chemical composition, antioxidant and anticholinesterase potentials of essential oil of Rumex hastatus D. Don collected from the North West of Pakistan. BMC Complement. Altern. Med. 2016, 16, 29. [CrossRef] [PubMed]

11. Shah, S.M.; Ayaz, M.; Khan, A.-U.; Ullah, F.; Farhan; Shah, A.-U.-H.A.; Iqbal, H.; Hussain, S. 1,1-Diphenyl, 2-picrylhydrazyl free radical scavenging, bactericidal, fungicidal and leishmanicidal properties of Teucrium stocksianum. Toxicol. Ind. Health 2015, 31, 1037-1043.

12. Domingues Passero, L.F.; Laurenti, M.D.; Santos-Gomes, G.; Soares Campos, B.L.; Sartorelli, P.; Lago, G.; Henrique, J. Plants used in traditional medicine: Extracts and secondary metabolites exhibiting antileishmanial activity. Curr. Clin. Pharmacol. 2014, 9, 187-204. [CrossRef]

13. Hazra, S.; Ghosh, S.; Hazra, B. Phytochemicals With Antileishmanial Activity: Prospective Drug Targets. In Studies in Natural Products Chemistry; Elsevier: New York, NY, USA, 2017; Volume 52, pp. 303-336.

14. Cabanillas, B.J.; Le Lamer, A.-C.; Castillo, D.; Arevalo, J.; Estevez, Y.; Rojas, R.; Valadeau, C.; Bourdy, G.; Sauvain, M.; Fabre, N. Dihydrochalcones and benzoic acid derivatives from Piper dennisii. Planta Med. 2012, 78, 914-918. [CrossRef] [PubMed] 
15. Ghoneim, M.M.; Elokely, K.M.; Atef, A.; Mohammad, A.E.I.; Jacob, M.; Cutler, S.J.; Doerksen, R.J.; Ross, S.A. Isolation and characterization of new secondary metabolites from Asphodelus microcarpus. Med. Chem. Res. 2014, 23, 3510-3515. [CrossRef]

16. Flores, N.; Jiménez, I.A.; Giménez, A.; Ruiz, G.; Gutiérrez, D.; Bourdy, G.; Bazzocchi, I.L. Benzoic acid derivatives from Piper species and their antiparasitic activity. J. Nat. Prod. 2008, 71, 1538-1543. [CrossRef]

17. Verma, R.K.; Prajapati, V.K.; Verma, G.K.; Chakraborty, D.; Sundar, S.; Rai, M.; Dubey, V.K.; Singh, M.S. Molecular docking and in vitro antileishmanial evaluation of chromene-2-thione analogues. ACS Med. Chem. Lett. 2012, 3, 243-247. [CrossRef] [PubMed]

18. Lieke, T.; Nylen, S.; Eidsmo, L.; McMaster, W.; Mohammadi, A.; Khamesipour, A.; Berg, L.; Akuffo, H. Leishmania surface protein gp63 binds directly to human natural killer cells and inhibits proliferation. Clin. Exp. Immunol. 2008, 153, 221-230. [CrossRef] [PubMed]

19. Nadhman, A.; Nazir, S.; Khan, M.I.; Arooj, S.; Bakhtiar, M.; Shahnaz, G.; Yasinzai, M. PEGylated silver doped zinc oxide nanoparticles as novel photosensitizers for photodynamic therapy against Leishmania. Free Radic. Biol. Med. 2014, 77, 230-238. [CrossRef] [PubMed]

20. Nadhman, A.; Sirajuddin, M.; Nazir, S.; Yasinzai, M. Photo-inducedLeishmaniaDNA degradation by silver-doped zinc oxide nanoparticle: Anin-vitroapproach. IET Nanobiotech. 2016, 10, 129-133. [CrossRef]

21. Lee, N.; Bertholet, S.; Debrabant, A.; Muller, J.; Duncan, R.; Nakhasi, H. Programmed cell death in the unicellular protozoan parasite Leishmania. Cell Death Differ. 2002, 9, 53. [CrossRef]

22. Wanderley, J.L.M.; Barcinski, M.A. Apoptosis and apoptotic mimicry: The Leishmania connection. Cell. Mol. Life Sci. 2010, 67, 1653-1659. [CrossRef] [PubMed]

23. Paris, C.; Loiseau, P.M.; Bories, C.; Bréard, J. Miltefosine induces apoptosis-like death in Leishmania donovani promastigotes. Antimicrob. Agents Chemother. 2004, 48, 852-859. [CrossRef] [PubMed]

24. Kaczanowski, S.; Sajid, M.; Reece, S.E. Evolution of apoptosis-like programmed cell death in unicellular protozoan parasites. Parasit. Vect. 2011, 4, 44. [CrossRef]

25. Abouri, M.; El Mousadik, A.; Msanda, F.; Boubaker, H.; Saadi, B.; Cherifi, K. An ethnobotanical survey of medicinal plants used in the Tata Province, Morocco. Int. J. Med. Plants Res. 2012, 1, 99-123.

26. Osman, A.K.; Al-Ghamdi, F.; Bawadekji, A. Floristic diversity and vegetation analysis of Wadi Arar: A typical desert Wadi of the Northern Border region of Saudi Arabia. Saudi J. Biol. Sci. 2014, 21, 554-565. [CrossRef]

27. Hammiche, V.; Maiza, K. Traditional medicine in Central Sahara: Pharmacopoeia of Tassili N'ajjer. J. Ethnopharmacol. 2006, 105, 358-367. [CrossRef]

28. García, M.; Perera, W.H.; Scull, R.; Monzote, L. Antileishmanial assessment of leaf extracts from Pluchea carolinensis, Pluchea odorata and Pluchea rosea. Asian Pac. J. Trop. Med. 2011, 4, 836-840. [CrossRef]

29. Shah, S.M.; Ullah, F.; Hussain, S.; Khan, S.B.; Asiri, A.M.; Ahmad, S.; Khan, H.; Farooq, U. A new trypsin inhibitory phthalic acid ester from Heliotropium strigosum. Med. Chem. Res. 2014, 23, 2712-2714. [CrossRef]

30. Ovais, M.; Ayaz, M.; Khalil, A.T.; Shah, S.A.; Jan, M.S.; Raza, A.; Shahid, M.; Shinwari, Z.K. HPLC-DAD finger printing, antioxidant, cholinesterase, and $\alpha$-glucosidase inhibitory potentials of a novel plant Olax nana. BMC Complement. Altern. Med. 2018, 18, 1. [CrossRef]

31. Ayaz, M.; Junaid, M.; Ullah, F.; Sadiq, A.; Shahid, M.; Ahmad, W.; Ullah, I.; Ahmad, A.; Syed, N.i.H. GC-MS analysis and gastroprotective evaluations of crude extracts, isolated saponins, and essential oil from Polygonum hydropiper L. Front. Chem. 2017, 5, 58. [CrossRef]

32. Zohra, T.; Ovais, M.; Khalil, A.T.; Qasim, M.; Ayaz, M.; Shinwari, Z.K. Extraction optimization, total phenolic, flavonoid contents, HPLC-DAD analysis and diverse pharmacological evaluations of Dysphania ambrosioides (L.) Mosyakin \& Clemants. Nat. Prod. Res. 2019, 33, 136-142.

33. Ali, M.; Muhammad, S.; Shah, M.R.; Khan, A.; Rashid, U.; Farooq, U.; Ullah, F.; Sadiq, A.; Ayaz, M.; Ali, M. Neurologically potent molecules from Crataegus oxyacantha; isolation, anticholinesterase inhibition, and molecular docking. Front. Pharmacol. 2017, 8, 327. [CrossRef]

34. Ayaz, M.; Sadiq, A.; Wadood, A.; Junaid, M.; Ullah, F.; Khan, N.Z. Cytotoxicity and molecular docking studies on phytosterols isolated from Polygonum hydropiper L. Steroids 2019, 141, 30-35. [CrossRef]

35. Ayaz, M.; Junaid, M.; Ullah, F.; Subhan, F.; Sadiq, A.; Ali, G.; Ovais, M.; Shahid, M.; Ahmad, A.; Wadood, A. Anti-Alzheimer's Studies on $\beta$-Sitosterol Isolated from Polygonum hydropiper L. Front. Pharmacol. 2017, 8, 697. [CrossRef] [PubMed]

36. Ullah, I.; Shinwari, Z.K.; Khalil, A.T. Investigation of the cytotoxic and antileishmanial effects of Fagonia indica L. extract and extract mediated silver nanoparticles (AgNPs). Pak. J. Bot. 2017, 49, 1561-1568. 
37. Khalid, W.; Badshah, A.; Khan, A.-u.; Nadeem, H.; Ahmed, S. Synthesis, characterization, molecular docking evaluation, antiplatelet and anticoagulant actions of 1, 2, 4 triazole hydrazone and sulphonamide novel derivatives. Chem. Cent. J. 2018, 12, 11. [CrossRef]

38. Khan, H.; Nadhman, A.; Azam, S.S.; Anees, M.; Khan, I.; Ullah, I.; Sohail, M.F.; Shahnaz, G.; Yasinzai, M. In-vitro antileishmanial potential of peptide drug hirudin. Chem. Biol. Drug Des. 2017, 89, 67-73. [CrossRef] [PubMed]

39. Rauf, M.K.; Shaheen, U.; Asghar, F.; Badshah, A.; Nadhman, A.; Azam, S.; Ali, M.I.; Shahnaz, G.; Yasinzai, M. Antileishmanial, DNA Interaction, and Docking Studies of Some Ferrocene-Based Heteroleptic Pentavalent Antimonials. Arch. Pharm. 2016, 349, 50-62. [CrossRef] [PubMed]

40. Ovais, M.; Khalil, A.T.; Islam, N.U.; Ahmad, I.; Ayaz, M.; Saravanan, M.; Shinwari, Z.K.; Mukherjee, S. Role of plant phytochemicals and microbial enzymes in biosynthesis of metallic nanoparticles. Appl. Microbiol. Biotechnol. 2018, 102, 6799-6814. [CrossRef] [PubMed]

41. Ovais, M.; Zia, N.; Ahmad, I.; Khalil, A.T.; Raza, A.; Ayaz, M.; Sadiq, A.; Ullah, F.; Shinwari, Z.K. Phyto-Therapeutic and Nanomedicinal Approach to Cure Alzheimer Disease: Present Status and Future Opportunities. Front. Aging Neurosci. 2018, 10, 284. [CrossRef]

42. Ayaz, M.; Sadiq, A.; Junaid, M.; Ullah, F.; Subhan, F.; Ahmed, J. Neuroprotective and anti-aging potentials of essential oils from aromatic and medicinal plants. Front. Aging Neurosci. 2017, 9, 168. [CrossRef]

43. Ayaz, M.; Subhan, F.; Sadiq, A.; Ullah, F.; Ahmed, J.; Sewell, R. Cellular efflux transporters and the potential role of natural products in combating efflux mediated drug resistance. Front. Biosci. (Landmark Ed.) 2017, 22, 732-756. [CrossRef]

44. Ovais, M.; Ahmad, I.; Khalil, A.T.; Mukherjee, S.; Javed, R.; Ayaz, M.; Raza, A.; Shinwari, Z.K. Wound healing applications of biogenic colloidal silver and gold nanoparticles: Recent trends and future prospects. Appl. Microbiol. Biotechnol. 2018, 102, 4305-4318. [CrossRef] [PubMed]

45. Ayaz, M.; Junaid, M.; Ullah, F.; Sadiq, A.; Subhan, F.; Khan, M.A.; Ahmad, W.; Ali, G.; Imran, M.; Ahmad, S. Molecularly characterized solvent extracts and saponins from Polygonum hydropiper L. show high anti-angiogenic, anti-tumor, brine shrimp, and fibroblast NIH/3T3 cell line cytotoxicity. Front. Pharmacol. 2016, 7, 74. [CrossRef] [PubMed]

46. Ahmad, S.; Ullah, F.; Zeb, A.; Ayaz, M.; Ullah, F.; Sadiq, A. Evaluation of Rumex hastatus D. Don for cytotoxic potential against HeLa and NIH/3T3 cell lines: Chemical characterization of chloroform fraction and identification of bioactive compounds. BMC Complement. Altern. Med. 2016, 16, 308. [CrossRef]

47. Seo, D.-J.; Kim, K.-Y.; Park, R.-D.; Kim, D.-H.; Han, Y.-S.; Kim, T.-H.; Jung, W.-J. Nematicidal activity of 3, 4-dihydroxybenzoic acid purified from Terminalia nigrovenulosa bark against Meloidogyne incognita. Microb. Pathog. 2013, 59, 52-59.

48. Del Olmo, A.; Calzada, J.; Nuñez, M. Benzoic acid and its derivatives as naturally occurring compounds in foods and as additives: Uses, exposure, and controversy. Crit. Rev. Food Sci. Nutr. 2017, 57, 3084-3103. [CrossRef] [PubMed]

49. Olivier, M.; Gregory, D.J.; Forget, G. Subversion mechanisms by which Leishmania parasites can escape the host immune response: A signaling point of view. Clin. Microbiol. Rev. 2005, 18, 293-305. [CrossRef]

50. Kakarsulemankhel, J.K. Leishmaniasis in Pak-Afghan Region. Int. J. Agric. Biol. 2011, 13, 611-620.

51. Wulsten, I.F.; Costa-Silva, T.A.; Mesquita, J.T.; Lima, M.L.; Galuppo, M.K.; Taniwaki, N.N.; Borborema, S.E.; Da Costa, F.B.; Schmidt, T.J.; Tempone, A.G. Investigation of the anti-Leishmania (Leishmania) infantum activity of some natural sesquiterpene lactones. Molecules 2017, 22, 685. [CrossRef]

(C) 2019 by the authors. Licensee MDPI, Basel, Switzerland. This article is an open access article distributed under the terms and conditions of the Creative Commons Attribution (CC BY) license (http://creativecommons.org/licenses/by/4.0/). 